\title{
Performance tests
}

It is known that nutritional deficiency leads to changes in personality, and to decreased performance in physical and psychomotor tests. There appears to be no report of the use of mental or psychomotor tests as a method of assessing nutritional state. There are, however, many reports of the use of physical tests for this purpose. The commonest are those in which a dynamometer is used to determine the strength of grip or of lumbar pull (e.g. Yudkin, 1944a, b, c). In all of these it is essential that psychological factors such as incentive should be recognized and well controlled.

The results of these tests suggest that they can give information of a similar kind to that given by the anthropometric tests. In other words, the performance tests do not say very much about the nutritional state of an individual, but groups can be compared, and changes in groups or individuals allow conclusions to be drawn about changes in nutritional state.

There are few studies of correlation between performance tests and other methods of assessing nutritional state, such as those of Milligan \& Lewis-Faning (1942a, $b, c$, $d, e, f)$ and especially of Jokl and co-workers (e.g. Jokl, 1946). Much more remains to be done before performance tests can be of any great value in assessing nutritional state.

\section{REFERENCES}

Friend, G. E. \& Bransby, E. R. (1947). Lancet, 253, 677.

Jenss, R. M. \& Souther, S. P. (1940). Publ. U.S. Dep. Labor Child. Bur. no. 263, p. 121. Jokl, E. (1946). Grovoth, ro, I.

Jones, R. H. (1938). F.R. statist. Soc. 101, I.

Milligan, E. H. M. \& Lewis-Faning, E. (1942a). Med. Offr, $5^{8,} 77$.

Milligan, E. H. M. \& Lewis-Faning, E. (1942b). Med. Offr, 58, 85 .

Milligan, E. H. M. \& Lewis-Faning, E. (1942c). Med. Offr, 58, 93.

Milligan; E. H. M. \& Lewis-Faning, E. (1942d). Med. Offr, 58, 101.

Milligan, E. H. M. \& Lewis-Faning, E. (1942e). Med. Offr, 58, 109.

Milligan, E. H. M. \& Lewis-Faning, E. (1942f). Med. Offr, 58, 117.

Wetzel, H. C. (194I). Y. Amer. med. Ass. 116, 1187.

Widdowson, E. M. \& McCance, R. A. (1944). Lancet, 247, 152.

Yudkin, J. (1944a). Brit. med. Y. ii, 201.

Yudkin, J. (1944b). Med. Offr, 72, 93.

Yudkin, J. (1944c). Med. Offr, 72, 101.

Yudkin, J. (1944d). Lancet, 247, 384.

\section{Glinical Surveys and Correlation with Blochemical, Somatometric} and Performance Measurements

\author{
By H. M. Sinclair, Wellcome Laboratory of Human Nutrition, \\ University of Oxford
}

Results given below were obtained by the staff of the Oxford Nutrition Survey, and I am indebted to the former members of the staff for them. But before discussing results we should consider their interpretation and the validity of the methods by which they are obtained. 
In discussing clinical surveys it is important to distinguish between physical state, health and nutriture. There are two types of nutritional survey now being made in this country, both of which are concerned to a large extent with physical state. They may be discussed in turn.

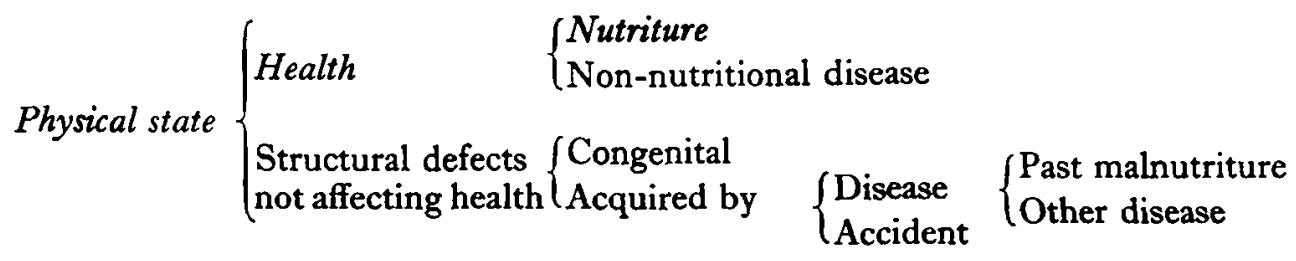

\section{General assessment by inspection}

This was introduced by the Board of Education in 1907, revised in 1934, and is still used by school medical officers. Unfortunately, the method assesses muscular development and physique more than general nutriture; Jones (1938) showed that experienced school medical officers were not consistent with one another in grading children, and one experienced doctor was not likely to be consistent with himself on a subsequent occasion. It seems that the Ministry of Education assessment has no advantages, and has certain disadvantages, over simple records of height and weight; and the time has probably come for it to be abandoned in its present form.

\section{Ministry of Health rapid clinical surveys}

These were started by Dr Sydenstricker in June 1942. His technique was essentially a rapid inspection of the skin, hair, tongue and mucous membranes of the mouth, and a slit-lamp examination of the cornea and scleral conjunctiva; he also recorded certain data about the teeth, including the presence of dentures. In addition, he noted what he called 'general physical status', dividing it into 'good', 'satisfactory' and 'poor'.. He made no general physical examination and performed no laboratory tests.

This type of rapid clinical survey was carried on very carefully by Drs Stannus, Hawes, Adcock and Fitzgerald, slight modifications in the technique being made at times (Magee, 1944; Adcock \& Magee, 1945, 1946a, $b$; Adcock, Magee \& Milligan, 1947). More recently Adcock, Hammond \& Magee (1947) have analysed statistically the results on 335 I children aged 8-1 5 and on 3326 adults to ascertain the relation between the incidence of the clinical signs and the general physical status (in Sydenstricker's terminology). In comparisons of this sort it is extremely important to be clear about the meaning of different terms. By 'general physical status' Sydenstricker understood 'past nutritional conditions plus hereditary influences, rather than the present state of nutrition'. Adcock, Hammond \& Magee (1947) use eight very slightly different terms for this one concept, the main variations being 'nutritional state', 'grade of nutrition', 'nutritional assessment', and 'clinician's nutritional grading'. This assessment is based in Adcock's (Adcock, Hammond \& Magee, i947) examinations on nineteen 'grading criteria', many of which have no relation to present nutriture. It is not surprising that there is a high correlation between the grading criteria and general 
physical status, and this does not justify the statement that 'the grading criteria singly and collectively are indicative of the nutritional state as at present understood by the clinician'.

It is also not surprising therefore that no positive correlation was found between the incidence of the clinical signs (such as gingivitis or folliculosis) and the general physical status; none would be expected. For instance, a child with scurvy does not necessarily have subnormal muscle development, diminished or excess subcutaneous fat, or poor posture. Adcock, Hammond \& Magee (1947) next correlated the clinical signs with 'an internal factor (the general nutritional factor) responsible for the signs'. Since they found a negligible agreement they concluded that 'the presence of these signs is not a dependable expression of the general state of nutrition'. But there is no single factor responsible for clinical signs that may be caused by a variety of factors including different types of nutritional deficiency. So this failure to find a correlation does not mean that the clinical signs are of no use in the assessment of nutriture. And some of the clinical signs they use, such as dandruff, acne, pityriasis, ichthyosis and pinguecula, are not nutritional in origin. It was invaluable to have Dr Sydenstricker here in the war to reassure us about the nutriture of the population by showing that there was a low incidence of the clinical signs he sought, and information along those lines should still be, and is being, collected; but I think the surveys should be extended to include the record of symptoms, of other clinical signs, and of somatometric and biochemical data.

\section{Symptoms}

A medical history is essential in the proper assessment of nutriture. The most useful symptoms are: change in body-weight, muscle pains or cramps including pain on rising from a chair, sore tongue, sore eyes, rapidly failing vision, paraesthesiae, weakness or fatigue, nycturia, diarrhoea; information about menstruation and lactation should be obtained when relevant. In general, symptoms must be accepted with great caution. One person will suffer in stoic silence grave insults to the body; another will whine about trivial or even imaginary ills. Symptoms of nycturia and diarrhoea were particularly common in Holland and Germany; in our initial surveys in Germany in the autumn of 1945 , the incidence of nycturia in the Ruhr and in Berlin was about $50 \%$ (males, nycturia in $52 \%$ of 1469 persons; females, nycturia in $46 \%$ of rogr persons). But in Great Britain to-day the incidence of most of these symptoms is probably very low.

\section{Clinical signs}

I have already suggested that some of the twenty-nine clinical signs recorded in the Ministry of Health surveys are not very relevant in nutrition surveys. For rapid nutritional surveys we introduced a card with a double row of holes around the edge on the Copeland-Chatterson principle (Clarke, r936), so that the incidence of signs and symptoms can be rapidly recorded and then punched for sorting; we also punch the results direct on to Hollerith cards without further coding. Our card is being used in the surveys in Germany and has also been adopted by Dr Pett for the Canadian Government. It is desirable to have listed on the card all important signs, whether common or 
very rare; there is no disadvantage in having a space for recording the incidence of a rare sign if it happens to be found. And it is important to record signs in four grades: absent, mild, marked and severe.

The main signs recorded are those in Table 1 . Some (such as pingueculae) are not nutritional in origin, and others are exceedingly rare in Great Britain.

Table 1. List of clinical signs recorded on cards used by the Oxford Nutrition Survey Skin-hair-nails

1. Extent of examination

2. Pallor, suborbital pigmentation, generalized pigmentation (and depigmentation), erythema, ecchymoses, perifollicular petechiae

3. Eczema, 'sores' and unhealed fesions, nutritional seborrhoea, pellagrous dermatosis, crackling, pityriasis sicca, generalized xeroderma, desquamation

Tongue

Red, magenta

Denuded filiform papillae

Pebbled filiform papillae

Fissures

Ulcers

Swollen
Blepharitis

Conjunctivitis

Conjunctival opacity

Pingueculae

Xerosis conjunctivae

Bitot's spots

Pterygium

Obesity

Thinness

Thyroid gland enlarged

Active rickets/osteomalacia

Nutritional oedema

Non-nutritional oedema

'Poor nutriture'
4. Diminished elasticity, atrophy, thickening, folliculosis, follicular hyperkeratosis

5. Folliculitis, infestations

6. Hypochromotrichia. Other hair abnormalities

7. Onychodystrophy
Gums

Red or purple

Swollen

Bleeding

Pyorrhoea
Mucous membranes

Cheilosis

Mycterosis

Angular stomatitis

Aphthae

Eyes

Corneal vascularization

Active vascularization

Other vascularization

Corneal opacity, ulcer

Photophobia

Lacrimation

Miscellaneous

Stretch reflexes diminished

Vibration sense diminished

Paresis

Bulbar palsy

Muscle tenderness

Myotatic irritability

'Nutritional group'

In the examination of the skin, it is essential to record the extent of the examination. The incidence of gingivitis must be assessed only in those who have teeth; it is very rare for edentulous persons to have gingivitis. We have found no relation between the incidence of red gums and plasma values for ascorbic acid. The presence of an upper denture must be taken into account in assessing the incidence of denudation of the filiform papillae of the tongue; Table 2 shows that those who have an upper denture are twice as likely to have a smooth tongue.

There are many difficulties in the interpretation of clinical signs. For instance, the mere incidence of folliculosis gives little information. Hyperkeratosis of the hair follicles can undoubtedly be caused by deficiency of ascorbic acid and can probably be caused by deficiency of vitamin $A$ or of unsaturated fatty acids. The commonest form is that which occurs especially at puberty, particularly in obese persons; it is not 
caused by dietary deficiency. In this common form there is no generalized xerosis which contrasts strongly with a rare but very important form that resembles generalized goose-skin; this type, which occurs on the sides of the chest as well as all over the arm, can certainly be caused by caloric deficiency and could be seen recently in

Table 2. Percentage incidence of denudation of filiform papillae found by the Oxford Nutrition Survey

Incidence of denudation in persons

Place and group
of population
Holland, all ages,
all sex groups
Holland, men
$20-44$ years
Holland, women,
20-44 years
England, pregnant
women

Exarniner
Sinclair
Borst
Sinclair and
Borst
Sinclair and
. Borst
Sinclair

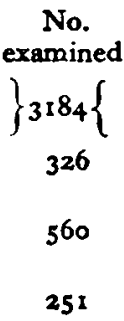

$\begin{array}{cc}\begin{array}{c}\text { With } \\ \text { denture }\end{array} & \begin{array}{c}\text { Without } \\ \text { denture }\end{array} \\ 51 & 22 \\ 65 & 21 \\ 46 & 28 \\ 61 & 30 \\ 44 & 18\end{array}$

Table 3. Percentage incidence of clinical signs in schoolchildren (Sydenstricker, unpublished; Sinclair, unpublished)

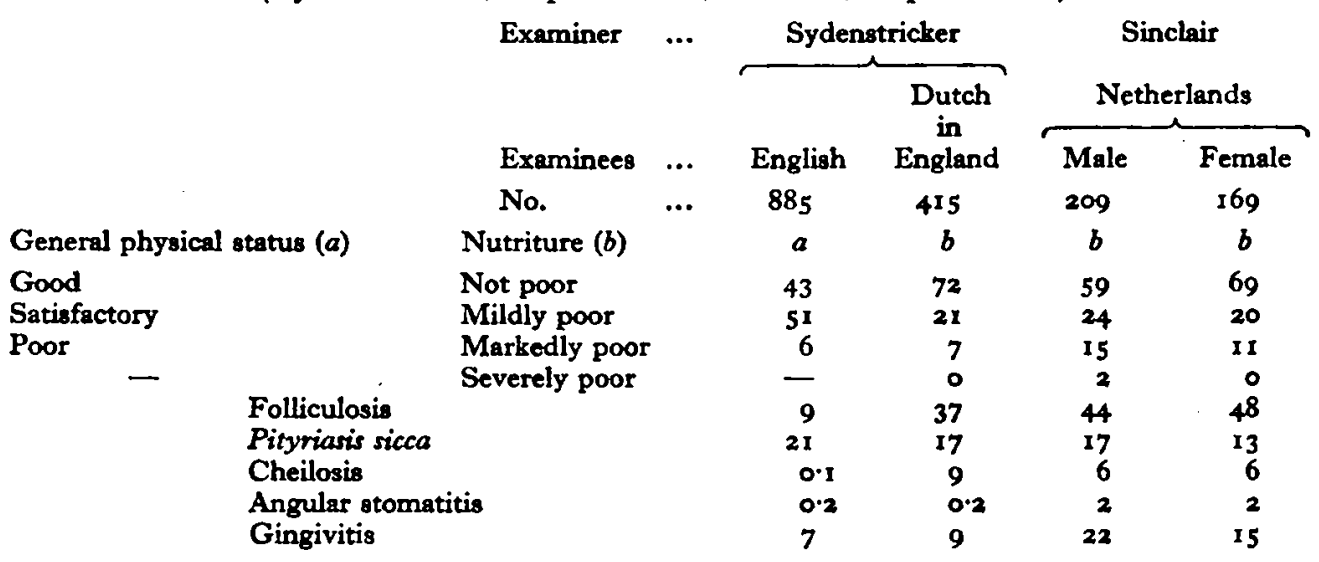

Germany but very rarely in this country. Table 3 shows that Sydenstricker found a higher incidence of folliculosis in the Dutch children, evacuated from liberated parts of the Netherlands to this country in 1945, than in English children; the incidence was also high in the Netherlands in May-June 1945, but there was no difference in the mean plasma vitamin $A$ of boys with folliculosis (mean, 86.8 i.u. $/ 100 \mathrm{ml}$.) and of those without (mean, 87.6 i.u./100 ml.). However, of $87 \mathrm{I}$ persons examined in Holland, the incidence of folliculosis in those with plasma vitamin A values below 30 i.u./100 ml. was $35 \%$, whereas the incidence in those with plasma values not less than 30 was $23 \%$. This difference, which is not statistically significant, is consistent with the belief that vitamin A deficiency is associated with some but not all cases of folliculosis. We found no significant relation between the incidence of folliculosis and plasma levels for ascorbic acid. 
Merely to record the incidence of clinical signs does not get one very far. The main purpose of recording clinical signs is to make a diagnosis, and, as in clinical practice, this must be done by taking into consideration the presence and degree of various signs, the medical and dietary histories, and other relevant factors such as somatometric data, functional facts or biochemical estimations.

\section{Somatometric data}

During the past several years there has been a marked increase in the rate of growth of children, although in England and the U.S. the adult male height has remained unchanged. It has not been shown that this increase in rate is necessarily advantageous; indeed, it may be undesirable, since the long time taken to reach maturity is characteristic of the human genus. It is known from the work of Wolbach that in young rats and guinea-pigs fed on diets containing large amounts of vitamin $A$ there is a great

\section{Table 4. Percentage incidence of clinical signs in relation to weight of child}

(The numbers of children examined are given in brackets.)

$\begin{array}{lcccc} & \text { English schoolboys, } 1942 & \text { Dutch children in England, I945 } \\ \text { Clinical sign } & \begin{array}{c}\text { Overweight' } \\ (62)\end{array} & \begin{array}{c}\text { 'Underweight' } \\ (86)\end{array} & \begin{array}{c}\text { 'Overweight' } \\ (63)\end{array} & \begin{array}{c}\text { 'Underweight' } \\ (352)\end{array} \\ \text { Folliculosis } & 64 & 62 & 33 & 38 \\ \text { Pityriasis sicca } & 23 & 27 & 19 & 16 \\ \text { Smooth tongue } & 13 & 12 & 0 & 0.6 \\ \text { Gingivitis } & 29 & 27 & 3 & 10 \\ \text { Poor nutriture } & 3 & 9 & 6 & 28\end{array}$

acceleration of bone growth so that 'it is possible to get the equivalent of a year's growth in a ten to fifteen day period' (Wolbach, 1945); the new bone is inadequately calcified and fractures easily. But a great acceleration of growth of this type seems to be the goal of many nutritionists despite its inconveniences. In adults, there is a tendency for weight to be conserved by activity being diminished when caloric intake falls.

The Dutch children who were evacuated to England during the war were nearly normal in height but low in weight, and the same is found in various groups of undernourished German children. To correlate the incidence of clinical signs with underweight, we have taken children above and below the statistically normal weight for age and height, and tabulated the incidence of certain clinical signs; Table 4 shows that these are not more common in underweight children.

\section{Functional measurements}

The testing of the rod threshold of the dark-adapted eye is very valuable in the diagnosis of deficiency of vitamin A provided a therapeutic test is done if a poor value is obtained. In our experiment on induced deficiency of vitamin A in volunteers in 1942 , there was an inverse correlation between the rod threshold of the dark-adapted eye and the plasma vitamin $A$ in the seven subjects who became definitely deficient. 
Capillary fragility has in our work shown no correlation with ascorbic acid in different parts of blood or in urine, and gum fragility has been equally disappointing. The measurement of nerve accommodation is promising for the diagnosis of deficiency of vitamin $B_{1}$. Tests of strength seem to be useless, but tests of endurance may be useful.

\section{Biochemical estimations}

We have used a large number of different biochemical estimations in nutritional surveys, and these have proved very valuable. Estimations of certain nutrients, such as ascorbic acid or vitamins of the B complex, are much more useful in a tissue such as leucocytes than in whole blood or plasma. Little is known, however, about the interpretation of blood values in man, and even less about the interpretation of urinary values. We have recently correlated various biochemical results with clinical results,

Table 5. Correlation coefficients for ascorbic acid in different parts of 626 samples of human blood, obtained in analysis done by the Oxford Nutrition Survey

$\begin{array}{lccc} & \text { Whole blood } & \text { Plasma } & \text { Erythrocytes } \\ \text { Plasma } & 0.97 & - & - \\ \text { Erythrocytes } & 0.91 & 0.89 & - \\ \text { Leucocytes } & 0.62 & 0.52 & =0.56\end{array}$

Whole blood estimated and whole blood calculated, $r=0.98$.

but there are dangers in such correlations. First, there may be a causal relation between two variates although there is no correlation between them. The dietary intake of ascorbic acid affects the ascorbic acid in both plasma and leucocytes; it affects the former very quickly but the latter slowly, and therefore no correlation between dietary ascorbic acid and the amount in leucocytes may be found. Estimations done mainly by Mr Lloyd and analysed by him and Mr Tweedie have shown the correlation coefficients between various estimations of ascorbic acid in 626 samples of human blood listed in Table 5. The correlation between the amount in whole blood estimated directly and that computed from the analyses in different parts of blood and from the erythrocrits and leucocrits is very high $(r=0.98)$, which is a tribute to the accuracy of six different estimations.

The second danger of correlations is similar to the post hoc fallacy. Because two variates show a high degree of correlation, there is not necessarily any causal relation of one to the other: When we analysed our findings for haemoglobin and for plasma protein on 1346 samples of human blood, we found there was a correlation $(r=0.49)$. But if pregnant women were excluded, there was no correlation. The pregnant women had low serum-protein and low haemoglobin values because there was haemodilution, and this fact gave rise to the positive correlation.

The dangers of correlations may be illustrated by reference to famine oedema. If the incidence of oedema is plotted against serum protein, a much higher incidence is found in people with low protein values in the two middle age-groups. But if this is analysed further, it is found that the mean values are not very different and are above 
$7 \mathrm{~g} . / 100 \mathrm{ml}$; in fact, the oedema is probably causing slightly low protein values by haemodilution, and the low protein is not causing oedema.

We have seen that clinical signs by themselves tell little; however, our wartime biochemical results show interesting differences. In our plasma protein results there are significant differences between the means of different groups of adults, which may vary as widely as from 7.17 to $8.09 \mathrm{~g}$ / $100 \mathrm{ml}$. In haemoglobin results obtained by the densitometric method, male students tended to have high values, nurses rather low values, and the Dutch boys evacuated to England during the war had normal values (mean, $13.06 \mathrm{~g} . / 100 \mathrm{ml}$.). We did a great many estimations of haemoglobin by the Haldane method, but I will not discuss them in view of the extensive results of the Medical Research Council's survey (Committee on Haemoglobin Surveys, I945); our mean results for different age groups and sexes follow the trend of the M.R.C. Survey, except for adolescent girls in the M.R.C. Survey who have a much higher mean value. Erythrocrit estimations show low mean results for working-class adult men and women in 1941, and for pregnant women from London in 1942.

Values for ascorbic acid in plasma are tremendously variable, depending on the season of the year. In an experiment in a factory from December 1942 to May 1943 , some workers were given supplements of ascorbic acid and their mean plasma value rose from 0.40 to $0.77 \mathrm{mg}$. $/ 100 \mathrm{ml}$.; those who received placebos had a mean value that fell from 0.44 to 0.25 . The results show great variation in the population: women in an Oxfordshire village in September 1942 had a mean of $0.92 \mathrm{mg} . / 100 \mathrm{ml}$, but women in Accrington in the first 2 months of the same year had a mean of 0.10 ; schoolboys in Oxford in the autumn of 1943 had a mean of 1.09 , whereas Oxfordshire schoolboys of the same age group in May of the same year had a mean of 0.35. Ascorbic acid values in leucocytes are much more important, and they also are variable: women in an Oxfordshire village in September 1942 had a mean of $20.8 \mathrm{mg} . / 100 \mathrm{~g}$, whereas adolescent boys in an Oxford factory in November 1942 had a mean of 10.3 .

Finally, vitamin A values in plasma are interesting: males in the $15^{-19}$ age group had a mean value of $\mathbf{r}_{32}$ i.u./100 $\mathrm{ml}$. if they were Oxford undergraduates in November 1943, but less than half that $(64.5)$ if they were factory workers near Oxford at exactly the same month in the previous year.

\section{Conclusion}

The object of nutritional surveys is to assess nutriture in samples of the population. I think Adcock, Hammond \& Magee (1947) are mistaken in looking for a single 'general nutritional factor' like Spearman's (1904) general intelligence (' $g$ '). General nutriture, which might be called ' $N$ ', only exists as a statistical concept, and can only be assessed when much more is known about the biochemical changes that occur in malnutriture. We cannot say whether a child with active rickets has worse nutriture than one with mild deficiency of half a dozen nutrients. And therefore we must define nutriture in terms of its properties: quality (the type of deficiency), degree (the extent of deficiency) and duration. To do this we need at present a battery of methods, particularly biochemical methods, indicated in Table 6.

We should turn from the old Board of Education classification assessing physical 
state to the combination of clinical, biochemical, and other methods in rapid nutritional surveys, together with independent body-weight surveys. We organized both these in Germany, and the latter are being made by the Ministry of Food in this country; it is good to know that Dr Magee is adding biochemical estimations to the clinical surveys

\section{Table 6. Methods for use in rapid assessments of nutriture in populations}

Primary. A clinical examination, a dietary history and a medical history are essential. The other methods placed in this group are valuable.

Secondary. The methods in this category are either valuable but need special apparatus or techniques*, or simple to perform but need further research for their interpretation or are otherwise of doubtful valuet.

Tertiary. The methods in this category have no proved value as yet for assessing nutriture in crosssectional studies.

\begin{tabular}{cl} 
& \multicolumn{1}{c}{ Primary methods } \\
Dietary & Dietary history \\
& Family inventory and \\
purchase method & Haemoglobin (B) \\
Chemical & Erythrocrit (or \\
erythrocyte count) (B) & Protein (without \\
& fractionation) (S) \\
& Ascorbic acid (B) \\
& Vitamin A and caro- \\
& tenoids (S) \\
& Phosphatase in \\
& children (S)
\end{tabular}

Functional

\begin{tabular}{|c|c|}
\hline Somatometric & $\begin{array}{l}\text { Weight } \\
\text { Height } \\
\text { Thickness of skin and } \\
\text { subcutaneous tissue }\end{array}$ \\
\hline Clinical & $\begin{array}{l}\text { Examination of skin, eyes } \\
\text { and other organs } \\
\text { Medical history } \\
\text { Blood pressure }\end{array}$ \\
\hline
\end{tabular}

Secondary methods

(a) Pyruvate (B)

(a) Protein with fractionation (S)

(a) Ascorbic acid (L)

(a) Vitamins of the $B$ complex (L)

(b) Phosphatase in adults (S)

(b) Fasting urinary excretion tests or load tests of water-soluble vitamins

(a) Rod threshold of dark-adapted eye

(b) Endurance tests

(b) Sitting height

(b) Pulse rate

(a) X-ray of hand and wrist in children
Tertiary methods

Minerals (B, S)

Prothrombase clotting

time (B)

Vitamins of the $B$ complex (B)

Saturation tests of water-soluble vitamins

- They are marked (a) in the table.

+ They are marked $(b)$ in the table.

(B) = determinations on whole blood, $(L)=$ determinations on leucocytes, $(S)=$ determinations on serum or plasma.

of the Ministry of Health. We are supposed to be discussing recent results in Great Britain, and I assume this means results obtained since the end of the war; but I fear I have paid little attention to these because there are very few recent results: the only clinical signs whose incidences are currently recorded in the latest publication of the Ministry of Health (Adcock, Magee \& Milligan, 1947) are folliculosis and gingivitis; folliculosis has been 'proved useless' according to the Ministry, and 'the evidence on 
the whole suggests that ascorbic acid is ineffective against the gingivitis commonly found in this country' according to Magee (1946). We badly need precise information about the nutriture in Britain at the present time.

\title{
REFERENCES
}

Adcock, E. W., Hammond, W. H. \& Magee, H. E. (1947). 7. Hyg., Camb., 45, 65.

Adcock, E. W. \& Magee, H. E. (1945). Mon. Bull. Minist. Hlth, 4, 136.

Adcock, E. W. \& Magee, H. E. (1946a). Mon. Bull. Minist. Hlth, 5, 36.

Adcock, E. W. \& Magee, H. E. (1946b). Mon. Bull. Minist. Hlth, 5, 198.

Adcock, E. W., Magee, H. E. \& Milligan, E. H. M. (1947). Mon. Bull. Minist. Hith, 6, 54.

Clarke, S. H. (1936). Nature, Lond., 137, 535.

Committee on Haemoglobin Surveys (1945). Spec. Rep. Ser. med. Res. Coun., Lond., no. 252.

Jones, R. H. (1938). F.R. statist. Soc. ror, I.

Magee, H. E. (1944). Mon. Bull. Minist. Hlth, 3, 146.

Magee, H. E. (1946). Brit. med. F. i, 475.

Spearman, C. (1904). Amer. F. Psychol. 15, 268.

Wolbach, S. B. (1945). Nutr. Rev. 3, 193.

\section{An Example of Difficulties in the Assessment of Nutritional Status}

\author{
By C. C. Ungley, Royal Victoria Infirmary, Newcastle-upon-Tyne
}

Some difficulties in the assessment of nutritional status are best illustrated by quoting a case.

After unaccustomed exercise a casual labourer developed oedema. Non-nutritional causes were excluded. The diet was poor because of duodenal ulcer pain, vomiting and poverty. Caries impeded mastication. Pre-war white bread, margarine, jam, sugar, tea, fish, potatoes and beer supplied $c$. $1700 \mathrm{Cal}$. and $0.5 \mathrm{mg}$. of vitamin $\mathrm{B}_{1}$ daily. The ratio of vitamin $B_{1}$ to non-fat calories slightly exceeded the accepted minimum requirement for his weight.

In Britain beriberi* seldom arises from dietary deficiency alone. In this patient, foods held up for $24 \mathrm{hr}$. by duodenal stenosis grew abundant yeasts, known to absorb vitamin $B_{1}$ and render it unavailable.

Apart from oedema, signs included intermittent tachycardia, wide pulse pressure with arterial sounds audible at zero, warm extremities, normal circulation time, slightly raised venous pressure, abnormal electrocardiograms, depressed deep reflexes, tender calves and plantar dysaesthesia. Adrenalin reduced diastolic pressure to zero. Vitamin $B_{1}$ excretion was negligible; response to loading doses, poor. Apparent vitamin $B_{1}$ in blood (Sinclair, 1939 ) was low.

During control and test periods the diet, low in vitamin $\mathrm{B}_{1}$, was weighed but unrestricted in amount. Oedema twice disappeared with rest in bed, only to reappear when the patient was allowed up. Weight changes mirrored these fluctuations. Eventually oedema increased, dyspnoea and substernal pain recurred.

- The term beriberi, used here for brevity, is by some authors applied to the syndrome only when it affects rice-eating peoples in tropical countries. Since multiple deficiencies are the rule, this condition is not necessarily synonymous with $B_{1}$ avitaminosis. 